\title{
Pitfalls of pediatric heart transplants
}

\section{John Worth Gamel}

Department of Ophthalmology, University of Louisville, Louisville, KY, USA

Correspondence to: John Worth Gamel. Department of Ophthalmology, University of Louisville, 300 Oread Road, Louisville, KY, USA. Email: jgamel44@gmail.com.

Submitted Oct 06, 2018. Accepted for publication Oct 17, 2018.

doi: $10.21037 /$ jtd.2018.10.60

View this article at: http://dx.doi.org/10.21037/jtd.2018.10.60

A recent PBS documentary portrayed the first scenario shown below of a heart transplant on an infant, while I recommend the second scenario.

First scenario-intervention:

(I) Thousands of dollars spent obtaining and transporting the donor heart;

(II) Hundreds of thousands of dollars spent performing the surgery;

(III) Millions of dollars spent keeping the child alive for the rest of his tormented life treating infections, malignancies, etc.;

(IV) No more kids-the parents will be too busy keeping this one alive. No grandkids;

(V) Immense grief for the parents and the kid, year after year-no way to measure that cost.

Second scenario-natural course:

(I) The infant dies and the couple mourns;

(II) The couple has more kids: overwhelming odds they will be healthy;

(III) The kids grow up to live productive lives. Lots of grandkids, maybe great grandkids;

(IV) The country saves millions of dollars. All the kids and grandkids pay taxes.

(V) Most important of all, the family avoids countless days of misery, pain, and grief.

Have those surgeons ever seen Bridge on the Rive Kwai? Who the hell's side are they on?

\section{Acknowledgements}

None.

\section{Footnote}

Conflicts of Interest: The author has no conflicts of interest to declare.

Cite this article as: Gamel JW. Pitfalls of pediatric heart transplants. J Thorac Dis 2018;10(11):E784. doi: 10.21037/ jtd.2018.10.60 